\title{
Institutional Aspects of Stimulating Small Business
}

\author{
Niiara B. Demiroglu* \\ Crimean Engineering and Pedagogical University in the name of Fevzi Yakubov, Uchebny Lane, 8, \\ Simferopol, Russia
}

\begin{abstract}
The article emphasizes the need to consider the institutional environment of small businesses as the basis for ensuring the implementation of the state strategy for business development during the period of overcoming the consequences of the economic crisis that arose as a result of the spread of a new coronavirus infection. The comparative characteristic of the definitions "institutional environment" and "institutional environment of entrepreneurship" of domestic and foreign researchers is carried out. Conclusions are made about the need to study the interaction of elements of the institutional environment of entrepreneurship development in Russia. The stages of formation of the institutional environment of small business are summarized. The composition and structure of small business entities in recent years have been analyzed. The problems affecting the decrease in the level of the business climate are systematized. The institutions for supporting small businesses (the fund for support (development) of SMEs in the region, the SME corporation, Skolkovo, territories of advanced socio-economic development, special economic zones, industrial parks, etc.), which provide various types of support for entrepreneurs: subsidies, tax incentives, preferential lending, non-financial support, government guarantees. The role of the state as the initiator of the creation of various institutions that support the development of small business and implements programs for the strategic development of small and medium-sized businesses, stimulating the growth of investment potential, is emphasized. To conduct the research, the author used both theoretical and empirical methods.
\end{abstract}

\section{Introduction}

Small and medium business is a certain center in the formation of state economic policy in Russia. Entrepreneurship is seen as the key to economic growth, investment and innovation, job creation and social inclusion in the state. However, according to official statistics, small and medium-sized enterprises can now be determined by the size of employment and income received for the previous period. This is a large category that encompasses enterprises with different ownership structures, different numbers of employees and levels of economic activity. This point is taken into consideration in the course of this study. It is

\footnotetext{
*Corresponding author : dnib2008@ukr.net
} 
innovation and investment that are the most effective tools in the competition between small businesses and large corporations. At the same time, one should consider the significant influence of the institutional environment among other various types of external environment (economic, political, legal, social and other conditions) on the opportunities for entrepreneurship growth and the transition from an ordinary "startup" project to a transnational company with a high level of capitalization. A.A. Baitursunov emphasizes that "the presence of an effective and well-structured institutional environment for the functioning of entrepreneurial activity is a priority task, since it is the basis for ensuring the implementation of the state strategy for the development of entrepreneurship" [2, p. 476]. At the same time, it should be particularly noted that there is an acute need for the influence of high-quality institutions for the development of small and medium-sized enterprises during the crisis period. A decrease in the level of financial resources, and, consequently, a decrease in the business activity of small business entities, gives rise to the need for institutional changes.

\section{Problem Statement}

The development of economic relations in the period of globalization is associated with a number of problems. The study of the interaction of elements of the institutional environment will allow to generalize the negative factors affecting the business climate and assess the directions of support through the institutional formations of small business.

\section{Research Questions}

The study of institutional changes in the field of small and medium-sized businesses follows from the consideration of the essence of the institutional environment of entrepreneurship.

E. D. Vaisman and M.V. Podshivalova concluded that "unified methodological approaches to the interpretation of the institutional environment, a unified classification of its constituent elements have not yet been formed" [13, p. 29]. It is by highlighting the concept of "institutional environment" as a separate category and by studying the approaches to the interpretation of this term, the attempt to systematize it will allow to generalize the methodological aspects of identifying the institutional environment of small business. A review of literary sources made it possible to summarize the main interpretations of the concepts of "institutional environment", "institutional environment of entrepreneurship", "institutional environment of small business".

It is widely accepted that the term "institutional environment" was introduced by foreign economists L. Davis and D. North, who "understood the institutional environment as a set of fundamental political, social and legal rules that create a base for production, exchange and distribution" [4, p. 6]. The definition of the institutional environment by A.A. Auzan considers it as "a set of rules (social, political, legal, economic) that determine human behavior" [1, p. 53]. A review of literary sources allows us to conclude that most authors adhere to the consideration of the institutional environment as a system of rules and norms between economic entities [7, 9, 12].

By the institutional environment the authors N.G. Vovchenko and T.V. Epifanov mean "a set of formal and informal institutions, as well as mechanisms of state regulation of entrepreneurial activity, including the mechanisms of centralized support for small businesses by state authorities and the international community" [15, p. 300]. V.N. Rutsky and I.S. Pyzhev summarizing the institutional problems and prospects for the development of innovative entrepreneurship in the resource economy came to the conclusion that the 
following components of the institutional environment of innovative small business should be distinguished: subjects of the business environment, social characteristics of an entrepreneur, transaction costs of entrepreneurial activity, sectoral characteristics of the technological regime of entrepreneurship and institutional constraints and incentives to innovators in national and regional innovation systems [11, P. 132].

The conducted review of scientific research indicates the need to focus on the interaction of elements of the institutional environment system in order to overcome the crisis situation of small businesses as a result of the spread of a new coronavirus infection.

\section{Purpose of the Study}

The purpose of the study is to generalize the elements of the system of the institutional environment of small business taking into account the assessment of the dynamics of changes in the structure of small business entities in Russia in recent years.

\section{Research Methods}

During the study, the following theoretical methods were used: analysis and synthesis, the method of abstraction, induction and deduction, interpretation, in order to understand the mutual influence of factors that determine the dynamics of general development. In addition, the use of empirical research methods should be noted: the study of scientific works of domestic and foreign scientists-economists and the results of their research activities, observation, conversation, etc.

\section{Findings}

It should be emphasized that the institutional environment is characterized by constant changes. This is due to the changing business environment and the adopted regulations. At the same time, it is always necessary to conduct a thorough analysis of the benefits and losses obtained from the introduction of innovations:

Next, we will consider the basis of formation of the institutional environment. The stages of formation of the institutional environment of small business:

- determination of the goals and objectives of the development of small business;

- conducting a preliminary analysis of the advantages and disadvantages of introducing something new;

- search for analogs in domestic or foreign practice;

- creation of an implementation strategy, taking into account the goals of related institutions;

- development of a set of adaptation measures aimed at minimizing the costs of individual groups;

- carrying out the final calculation of benefits and losses from the introduction of the new institution.

The data obtained is compared with the available financial support in order to make an informed decision.

For the purpose of more effective formation of the institutional environment of small business, attention should be paid to the mechanism of state regulation. It is the system of state regulation and stimulation of entrepreneurship in the Russian Federation that constitutes the basis of the institutional environment. The author previously paid attention to the factors and methods of state regulation of small business [5]. 
The state, being the initiator of the creation of various institutions supporting the development of small businesses and implementing programs for the strategic development of small and medium-sized business, stimulates the growth of investment potential.

According to experts, small and medium-sized businesses are the engine of the economy of many countries. According to the Organization for Economic Co-operation and Development (OECD), in developed countries, from 60 to $70 \%$ of the employed population work in SMEs, in China - 80\%. The contribution of small and medium-sized businesses in the US is about $50 \%$, in the UK $-47 \%$, in Germany $-57 \%$, in China $-60 \%$, in India $45 \%$. In China, the SME sector owns $65 \%$ of patents, $75 \%$ of technical innovations and over $80 \%$ of new products. According to the World Bank, in developing countries in the next 15 years, four out of five new jobs will be created by small and medium-sized enterprises [14].

According to the studies, the experts determined the share of workers of small and micro-enterprises in the total number of workers in 2019 in the context of the constituent entities of the Russian Federation from 1, 7\% (in the Republic of Ingushetia) to $23.8 \%$ (in the Kaliningrad region). On average in the country, this indicator was $15.0 \%$ [10].

As the Minister of Economic Development of Russia Maxim Reshetnikov emphasized, "the total number of people employed in small business in Russia increased in 2020 compared to the previous year and amounted to almost 23 million people." At the same time, he noted a slight decrease in small businesses over the past year [8].

We summarize the dynamics of change in the number of small business entities in Table 1 .

Table 1. The structure of small businesses for 2016 - 2020 in the Russian Federation*

\begin{tabular}{|l|l|l|l|l|}
\hline $\begin{array}{l}\text { As at the date } \\
\text { of: }\end{array}$ & $\begin{array}{l}\text { Number of } \\
\text { SMP }\end{array}$ & $\begin{array}{l}\text { The sum of the } \\
\text { average number of } \\
\text { employees }\end{array}$ & $\begin{array}{l}\text { Average ratio } \\
\text { of workers to } \\
\text { SMEs }\end{array}$ & $\begin{array}{l}\text { Growth rate } \\
\text { (decrease) in the } \\
\text { number of SMEs in } \\
\text { relation to the } \\
\text { previous period,\% }\end{array}$ \\
\hline 10.01 .2017 & 5865780 & 15855749 & 2,70 & No Data Available \\
\hline 10.01 .2018 & 6039216 & 16106581 & 2,67 & 102,96 \\
\hline 10.01 .2019 & 6041195 & 15873589 & 2,63 & 100,03 \\
\hline 10.01 .2020 & 5916906 & 15321788 & 2,59 & 97,94 \\
\hline 10.01 .2021 & 5684561 & 15491144 & 2,73 & 96,07 \\
\hline $\begin{array}{l}\text { on average over } \\
5 \text { years }\end{array}$ & 5909532 & 15729770 & 2,66 & 99,25 \\
\hline
\end{tabular}

* - the table was compiled on the basis of data from the Unified Register of Small and Medium Enterprises [16].

The analysis of the structure of registered SMEs indicates a slight decrease in the number of small businesses in 2019 and 2020, which ranges from 3-4\%. This low value of reducing the number of small businesses is associated with the implementation of anti-crisis measures in the following main areas: concessional lending, support of demand and support for the regions of the country.

We should also pay attention to the sectoral composition of small businesses. It should be noted the following areas of activity, in which the largest number of SPMs was registered: construction of residential and non-residential buildings (15\%), road freight transport service $(15 \%)$, retail trade mainly of food products $(12 \%)$, rent and management of own or leased real estate $(10 \%)$, provision of services by hairdressers and beauty salons $(9 \%)$, etc.

The conditions for small and medium-sized businesses are characterized by the peculiarities of the entrepreneurial climate, the stable development of which will become 
the basis for the development of the institution of entrepreneurship in the Russian Federation.

We should also note the role of interaction between small business entities, the state and institutions of the entrepreneurship development (Figure 1).

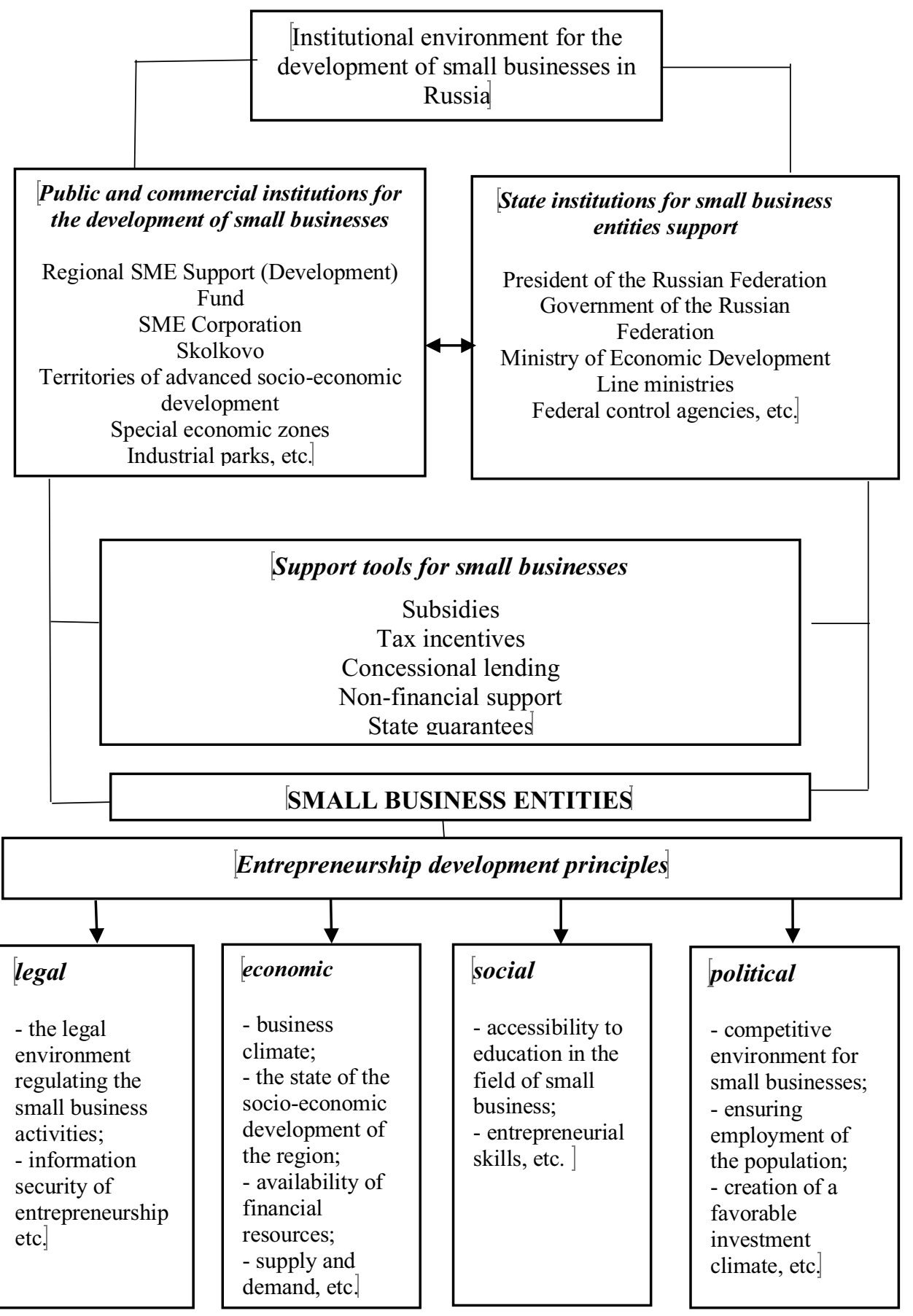

Fig. 1. The system of interaction of elements of the institutional environment of small business development 
The presented system reflects the interaction of elements of the institutional environment of small business. The characteristics of business development institutions at the federal level are presented in the work of O.V. Chistyakov and A.V. Babkin. The authors concluded that it is necessary in the future to conduct research in the field of small and medium-sized business development taking into account the impact of the proposed support measures from the institutions of business development [3, p. 135].

According to the report of the Russian Union of Industrialists and Entrepreneurs on the state of the business climate in 2019-2020, "the state of the business climate in Russia, according to $38 \%$ of business representatives, has not changed in $2019.34 .2 \%$ of respondents noted some deterioration in the business climate, and more than a quarter believe that the situation has improved in 2019" [6]. It is worth paying attention to the complex problems, highlighted by entrepreneurs, that do not contribute to the improvement of the business climate: fiscal policy, lack of qualified personnel, rising producer prices, difficulty in accessing credit resources, insufficient protection of property rights, a drop in the population's solvency associated with the spread of a new coronavirus infection, and others. The solution to these problems is possible with introducing state support for small businesses.

\section{Conclusion}

Over the past year, there have been significant changes in the institutional environment of entrepreneurship as a result of the introduction of restrictive measures in order to reduce the spread of the new coronavirus infection. This implies the need for a more detailed study of the interaction of elements of the system of the institutional environment of small business.

Comparative analysis of the concepts of "institutional environment" and "institutional environment of entrepreneurship" reveals a wide range of studies on this issue and the versatility of this category. The review of scientific works indicates the absence of unified methodological approaches to the interpretation of the definitions under consideration and the need to clarify the essence of the "institutional environment of small business" in further research.

The state occupies a special place in the system of the institutional environment of small business. Through the legislatively approved instruments of support with the help of public and commercial institutions of the development of small businesses, the state regulates the activities of entrepreneurs and provides support in order to overcome the crisis situation. Thus, it contributes to the improvement of the business climate and the solution of emerging problems.

\section{References}

1. Auzan, A.A. (2006). Institutsional'naya ekonomika: novaya institutsional'naya ekonomicheskaya teoriya [Institutional Economics: new institutional economic theory]. Moscow, 416 p. [in Rus.].

2. Baitursunov, A. A. (2018). Institutional Framework of the Incentive System for Small and Mediumsized Enterprises in the Republic of Kazakhstan. MIR (Modernizatsiia. Innovatsii. Razvitie) = MIR (Modernization. Innovation. Research). 2018; 9(3):475490. DOI: 10.18184/2079-4665.2018.9.3.475 - 490 [in Rus.]. DOI: 10.18184/20794665.2018.9.3.475-490.

3. Chistyakova, O.V. \& Babkin, A.V. (2019) Business development institutes as tool of state support of small and medium-sized innovative entrepreneurship, St. Petersburg 
State Polytechnical. University Journal. Economics, 12 (6) 128-138. DOI: 10.18721/JE.12611. [in Rus.].

4. Davis, L. \& North, D. (1971). Institutional Change and American Economic Growth. Cambridge. P. 6.

5. Demiroglu, N.B. (2019). Formy i metody gosudarstvennogo regulirovaniya malogo biznesa V Respublike Krym. Uchenyye zapiski Krymskogo inzhenernopedagogicheskogo universiteta. Simferopol'. Vol 2(64). pp. 76 - 81. [in Rus.].

6. Doklad Rossiyskogo soyuza promyshlennikov i predprinimateley o sostoyanii delovogo klimata v 2019-2020 godakh. Elektronnyy resurs. URL: https://rspp.ru/upload/iblock/888/doklad\%202020\%20oktyabr'.pdf. (data obrashcheniya 05.03.2021g.).

7. Islamutdinov, V. F. (2020). Institutsional'nyye izmeneniya $\mathrm{v}$ kontekste tsifrovoy ekonomiki. Journal of Institutional Studies, Vol. 12(3), pp. 142-156. DOI: 10.17835/2076-6297.2020.12.3.142-156 [in Rus.].

8. Maksim Reshetnikov: v 2020 godu chislennost' zanyatykh v MSP vyrosla do $23 \mathrm{mln}$ chelovek. Elektronnyy resurs. URL: https://www.economy.gov.ru/material/news/maksim_reshetnikov_v_2020_godu_chisle nnost_zanyatyh_v_msp_vyrosla_do_23_mln_chelovek.html. (data obrashcheniya 06.03.2021g.).

9. Pakhalov, A. M. (2016). Institutional design as a tool to improve the investment climate. Russian Entrepreneurship, Vol. 17(18), 2335-2350. DOI: 10.18334/rp.17.18.36551. [in Rus.].

10. Reyting regionov po vovlechennosti naseleniya $\mathrm{v}$ malyy biznes -2020 . Elektronnyy resurs. URL: https://riarating.ru/infografika/20200512/630169279.html. (data obrashcheniya 06.03.2021g.).

11. Rutskiy, V.N. \& Pyzhev, I.S. (2015). Institutsional'nyye problemy i perspektivy razvitiya innovatsionnogo predprinimatel'stva $\mathrm{v}$ resursnoy ekonomike. Zhurnal institutsional'nykh issledovaniy. Vol.4. Tom 7. pp. 128-137. [in Rus.].

12. Timokhina, G. S., Vagner, R., Myslyakova, YU. G. \& Popova O. I. (2020). Metodologicheskoye obespecheniye sravnitel'nogo issledovaniya institutsional'noy sredy v sfere upravleniya bytovymi otkhodami. Zhurnal ekonomicheskoy teorii. T. 17. Vol. 2. pp. 476-490. DOI: 10.31063/2073-6517/2020.17-2.19. [in Rus.].

13. Vaisman, E.D. \& Podshivalova, M.V. (2017). The Institutional Environment of Small Industrial Enterprises: Methodological Aspects of Identification. Bulletin of the South Ural State University. Ser. Economics and Management, vol. 11, no. 2, pp. 28-35. [in Rus.]. DOI: 10.14529/em170204. DOI: 10.14529/em170204.

14. Vliyaniye ekosistemy MSP na mirovuyu ekonomiku. Elektronnyy resurs. URL: https://tass.ru/pmef-2017/articles/4278934. (data obrashcheniya 06.03.2021g.).

15. Vovchenko, N. G. \& Epifanova, T. V. (2013). Otsenka institutsional'noy sredy predprinimatel'stva v Rossii. Teoriya i praktika obshchestvennogo razvitiya, Izdatel'skiy dom KHORS. Krasnodar. vol. 8, pp. 300-305. [in Rus.].

16. Yedinyy reyestr subyektov malogo i srednego predprinimatel'stva. Federal'naya nalogovaya sluzhba. Elektronnyy resurs. URL: https://ofd.nalog.ru/statistics.html. (data obrashcheniya 06.03.2021g.). 